\title{
Growth, feeding and distribution of the solenette Buglossidium luteum with particular reference to its habitat preference
}

\author{
R. Amara ${ }^{a^{*}}$, K. Mahé ${ }^{a}$, O. LePape ${ }^{b}$ and N. Desroy ${ }^{c}$
}

\author{
a'Université du littoral-Côte d'Opale, UMR CNRS 8013 ELICO, Avenue Foch, 62930 Wimereux, France \\ ${ }^{\mathrm{b}}$ Ifremer, Laboratoire d'écologie halieutique, BP 21105, 44311, Nantes Cedex 03, France \\ ${ }^{\mathrm{c}}$ Station Marine de Wimereux, Université de Lille I, UMR CNRS 8013 ELICO, BP 80, 28 Avenue Foch, 62930 \\ Wimereux, France \\ *: Corresponding author : rachid.amara@mren2.univ-littoral.fr
}

\begin{abstract}
Growth, condition, diet and spatial distribution of the solenette Buglossidium luteum (Risso, 1810) were investigated along the coasts of the French Atlantic, eastern English Channel and Southern Bight of the North Sea. Distribution and habitat preferences of solenette were analysed in relation to physical and biological features presumed to influence fish distribution. B. luteum was patchily distributed and concentrated in shallow muddy and muddy-sand bottoms moderately influenced by estuarine waters (euhaline waters). In the studied area, solenette seemed to find habitats suitable for growth. Food availability was not assumed to be a limiting factor for solenette distribution in contrast to abiotic factors such as salinity.
\end{abstract}

Keywords: Growth; Feeding; Distribution; Habitat suitability; Solenette 


\section{Introduction}

The solenette, Buglossidium luteum (Risso, 1810) is the smallest Soleidae in European waters, the adult only reaching 10-13 cm in length (Wheeler, 1969). This species is most abundant at depths ranging between 5 to $20 \mathrm{~m}$ along the south coast of England (English Channel) (Rogers et al., 1998) and 10 to $50 \mathrm{~m}$ in the southern North Sea (Baltus and Van der Veer, 1995). Is is rarely found inshore and does not make any pronounced migrations (Wheeler, 1969). Although flatfish have generally specific preferences for bottom substrate, Amezcua and Nash (2001) showed that the distribution and abundance of solenette are not related to the sediment type. Unlike plaice (Pleuronectes platessa), sole (Solea solea) and dab (Limanda limanda) which are the most abundant and widespread flatfish species in the shallow waters of the northeast Atlantic, solenette is patchily distributed and more specific in its habitat requirements (Baltus and Van der Veer, 1995; Rogers et al., 1998). Since it is not a commercial fish, detailed information on biology and ecology is lacking for this species and factors influencing the distribution or habitat requirements are misunderstood.

The aim of this study was to investigate the habitat preference of solenette along the French Atlantic, eastern English Channel and southern Bight of the North Sea coasts. The spatial distribution of the species was examined in relation to physical and biological features presumed to influence the distribution of $B$. luteum. Growth, condition and diet were analyzed and used to compare habitat suitability in which solenette were found.

\section{Material and Methods}

\subsection{Study area and sampling}

Fish were collected during autumn 1999 and 2000 in the Eastern Channel and southern Bight of the North Sea and during autumn 2000 and 2001 in the Bay of Biscay (Fig. 1). A total of 618 stations were sampled during daylight with a $3 \mathrm{~m}$ beam trawl (10x10 mm mesh codend) equipped with one tickler chain. Temperature and salinity were 
recorded at each station. All fish were identified and counted and density was calculated as the numbers of individuals per $1000 \mathrm{~m}^{-2}$.

\subsection{Analyses of spatial distribution}

To study the distribution and habitat requirements of solenette, a Generalized Linear Model was performed. This model, previously developed by Le Pape et al. (in press) to study the spatial distribution of sole nursery grounds, was built assuming a delta distribution. A binomial distribution for the presence of solenette was coupled to a lognormal distribution for density when solenette were present (Le Pape et al., in press). The maximum likelihood estimation for this model amounted to fitting one GLM to 0/1 values and another to positive abundance values (Stefansson, 1996). Physical parameters known to influence spatial distribution of flatfish (bathymetry, sediment structure, salinity, temperature, interannual variability and geographical area) were taken into account.

\subsection{Growth, condition and diet composition analyses}

The solenette were measured for total length and weighed. At each site, a sub sample of 4 fish by $5 \mathrm{~mm}$ size class was analysed for age and growth estimates. Age was estimated for 228 fish. The condition factor K (Fulton, 1911) of juvenile solenette (Lt $\leq 8$ $\mathrm{cm})$ was calculated for each fish with the formula $\mathrm{K}=\left(\mathrm{W} / \mathrm{L}^{3}\right) \times 100$, where $\mathrm{W}$ is the fresh weight (mg) and $\mathrm{L}$ is the total length (mm). This morphometric index assumes that heavier fish of a given length are in better condition.

A total of 215 individuals was examined for their stomach contents. Fish were divided into six size classes $(<40 ; 41-60 ; 61-80 ; 81-100 ; 101-120 ;>120 \mathrm{~mm})$ to study their diet during growth. Individuals analysed were randomly selected in each size class. All preys in the stomach contents were sorted under a binocular microscope, identified to the nearest taxon or species and counted. 


\section{Results}

\subsection{Distribution and habitat suitability}

Solenette are essentially located in shallow waters near riverine outflows of the Somme, Seine and Vilaine estuaries. However, the solenette is mainly absent from the river mouth of the largest studied estuaries (Loire and Gironde) (Fig. 2). Whatever the year considered, abundances were more important in the Eastern Channel than in the Bay of Biscay. The results of the model confirmed the estuarine influence on the solenette distribution (Fig. 3). This species is located in waters moderately influenced by estuaries, in front of small estuarine systems, and is rare in very estuarine waters (e.g. largest estuaries). The model also emphasized that solenette are rare in very shallow waters; the maximum densities being found from 5 to $15 \mathrm{~m}$ in the Eastern Channel and between 20-35 m in the Bay of Biscay on muddy and sandy-muddy bottom sediments. Sea water temperature does not influence solenette distribution.

\subsection{Growth, condition and feeding}

The size of the sampled fish varies between 2.3 and $12.5 \mathrm{~cm}$. The shape of the growth curve for the same sex is similar whatever the studied area considered (Fig. 4). Most growth occurs in the first year of life and continues at a relatively low and constant rate. The growth coefficient $(\mathrm{K})$, which determines the rate to which the fish reaches its maximum size, is higher for males $(\mathrm{K}=0.64)$ than for females $(\mathrm{K}=0.49)$ (Fig. 4). Except in Dunkirk where the majority (95\%) of the solenette caught where O-group juveniles, there are no significant differences in the length/weight relationship between the three main areas (Bays of Somme, Seine and Vilaine) (ANCOVA, p>0.05). However, there are significant differences (ANOVA, $\mathrm{P}<0.05$ ) in the condition factor $(\mathrm{K})$ of juvenile solenette, the lower values being recorded at Dunkirk and the highest in the Bay of Somme. The condition factor did not differ significantly between juvenile of the Bays of Seine and Vilaine. 
The solenette feeds on a wide range of bottom-living organism. Its diet was constituted of 33 preys belonging essentially to the 3 groups of benthic invertebrates: crustaceans (44.18 \%O: \% of occurrence, $77.20 \% \mathrm{~N}$ : \% by number), polychaetes (38.61 $\% \mathrm{O}, 5.84 \% \mathrm{~N})$ and molluscs $(21.01 \% \mathrm{O}, 14.78 \% \mathrm{~N})$. Whatever the area and the solenette size considered, crustaceans are numerically the most common prey. Among them, the cumacea, ostracoda and Harpacticoid copepods, characterized by their small size, are the main components of diet of individuals smaller than $6 \mathrm{~cm}$. For larger fish, the crustacean preys belong essentially to the malacostraca. The polychaetes, mainly Nephtys sp., although often found in the stomach of small individuals, are more important in the diet of fish $>8 \mathrm{~cm}$. For all size classes, the diet was completed by molluscs, mainly Abra alba and Macoma balthica. Some geographical differences in the diet were observed. Solenette fed on a wider range of prey species in the Bay of Biscay (27 species or taxa) than in the Eastern Channel (22 taxa or species). Polychaetes were more important in the diet of specimens from the Eastern Channel, whereas in the Bay of Biscay crustaceans and molluscs dominate the diet.

\section{Discussion}

Many environmental variables are assumed to be responsible for the distribution of fish population (e.g. Riley et al., 1981; Gibson, 1994). Several studies have examined environmental variables that affect flatfish distribution in shallow coastal areas and found salinity, temperature, depth and sediment type to be the dominant factors influencing distribution (Rogers, 1992, Norcross et al., 1999, LePape et al., in press). In the studied area, solenette is concentrated at the proximity of riverine outflows, in shallow muddy and muddy-sand bottoms moderately influenced by estuarine waters (in water salinities between 29 - 33). The dependence of flatfish for sediments is generally related both to the the ability to bury themselves and to the distribution of suitable prey (Gibson and Robb, 
1992; Gibson, 1994). As in other areas, the solenette feeds on a wide range of bottomliving organisms (Nottage and Perkins, 1983; Darnaude et al., 2001). Geographical diet differences, as observed in the present study, are common among flatfish (De Groot, 1971) and can reflect the high trophic adaptability of solenette to the available preys. The uniformity of the seabed environment along the French coast of the Eastern Channel and southern Bight of the North Sea support a uniform distribution of benthic fauna (i.e. potential preys) (Desroy et al., 2003). Solenette feeds on the same preys as other flatfish species of the studied area (Amara et al., 2001). The absence or scarcity of solenette of areas (e.g. bay of Canche or the southern Bight of the North Sea) where growth and feeding conditions are suitable for sole, plaice and dab (Amara et al., 2001; Amara and Paul, 2003) suggests that food availability is not a limiting factor of solenette distribution. The length at age and the growth parameters obtained in the present study are similar to those described in others areas (Nottage and Perkins, 1983, Deniel 1990; Baltus and Van der Veer, 1995). The fact that no geographical pattern in solenette growth and condition were observed also suggest that solenette find suitable habitat for their growth in the studied areas and that other factors may be responsible for the patchily distribution of this species.

If solenette are concentrated at the proximity of riverine outflows, this species is mainly absent from the mouth of the largest estuaries. Along the coasts of England and Wales, the O-group solenette occur mainly in water salinities between 30 - 35 and are absent in water salinities < 20 (Riley et al., 1981). As a consequence, they are abundant on the south coast and absent on the east coast of England and notably near the Thames estuary, where the salinity is lower, whereas other flatfish species (e.g. sole, plaice and dab) are very abundant (Rogers et al., 1998). In the southern North Sea, neither the estuarine Dutch Wadden Sea nor the very shallow coastal zone is used as a nursery area by this species. The distribution and movements of several flatfish species have been 
correlated with salinity (Riley et al., 1981; Marchand, 1993). The present study confirms that the solenette avoid low salinity waters. This species which never penetrates into estuaries (Wheeler, 1969) and intertidal areas (Amara and Paul, 2003) can be defined as a 'peri-estuarine species' (Lagardère, 1982). Temperate estuaries are known to provide important nursery habitats for euryhaline fishes which find large food resources. In the studied area, the distribution of solenette clearly differs from that of sole and plaice, which show a euryhaline tendency and use very shallow coastal and estuarine areas as nursery grounds (Zijlstra, 1972; Marchand, 1993; Van der Veer et al., 1990). Although nothing is known about the physiology of the solenette, this species may be intolerant of the often harsh physical conditions encountered in the very shallow and at the proximity of large riverine outflows and not able to rapid physiological adjustments in order to maintain a functional homeostasis. Many questions remain to be answered concerning the physiological and behavioural mechanisms by which fish select preferred habitats. Experimental studies are needed to evaluate the tolerance of solenette to several abiotic factors such as salinity.

\section{Acknowledements}

This study was carried out with the financial assistance of the French Ministère de l’Aménagement du Territoire et de l'Environnement (projet LITEAU). Thanks are also due to J. Morin, M.L. Cochard, Y. Désaunay and D. Guerrault for their contribution in the sampling. 


\section{References}

Amara, R., Paul, C., 2003. Seasonal patterns in the fish and epibenthic crustaceans community of an intertidal zone with particular reference to the population dynamics of plaice and brown shrimp. Estuar. coast. Shelf Sci. 56, 809-820.

Amara, R., Laffargue, P., Dewarumez, M., Maryniak, C., Lagardère, F., Luzcac, C., 2001. Feeding ecology and growth of 0-group flatfish (sole, dab and plaice) on a nursery ground (Southern Bight of the North Sea). J. Fish Biol. 58, 788-803.

Amezcua, F., Nash, R.D.M., 2001. Distribution of the order Pleuronectiformes in relation to the sediment type in the North Irish Sea. Neth. J. Sea Res. 45, 293-301.

Baltus, C.A.M., Van der Veer, H.W., 1995. Nursery areas of solenette Buglossidium luteum (Risso, 1810) and scaldfish Arnoglossus laterna (Walbaum, 1792) in the southern North Sea. Neth. J Sea Res. 34, 81-88.

Darnaude, A.M., Harmelin-Vivien, M.L., Salen-Picard, C., 2001. Food partitioning among flatfish (Pisces : Pleuronectiforms) juveniles in a Mediterranean coastal shallow sandy area. J. Mar. Biol. Assoc. UK. 81, 119-127.

De Groot, S.J., 1971. On the interrelationships between morphology of the alimentary tract, food and feeding behaviour in flatfishes (pices : pleuronectiformes). Neth. J. Sea Res. 5, 121-196.

Deniel, C., 1990. Comparative study of growth of flatfishes on the west coast of Brittany. J. Fish Biol. 37, 149-166.

Desroy, N., Warembourg, C., Dewarumez, J.M., Dauvin, J.C., 2003. Macrobenthic resources of the shallow soft-bottom sediments in the eastern English Channel and southern North Sea. ICES J. Mar. Sci. 60, 120-131.

Fulton, T.W., 1911. The Sovereignty of the Sea. London, England.

Gibson, R.N., 1994. Impact of habitat quality and quantity on the recruitment of juvenile flatfishes. Neth. J. Sea Res. 32, 191-206.

Gibson, R.N., Robb, L., 1992. The relationship between body size, sediment grain size and the burying ability of juvenile plaice, Pleuronectes platessa L. J. Fish Biol. 40, 771-778.

Lagardère, F., 1982. Environnement péri-estuarien et biologie des Soleidae dans le Golfe de Gascogne (Zone Sud) à travers l'étude du céteau, Dicologlossa cuneata (Moreau 1881). Ph. D. Thesis, Sci. Univ. Aix-Marseille, France, unpublished.

Le Pape, O., Chauvet, F., Mahévas, S., Lazure, P., Guérault, D., Désaunay, Y., (in press). Quantitative description of habitat suitability for the juvenile common sole (Solea solea L.) and contribution of different habitats to the adult population in the Bay of Biscay. J. Sea Res.

Marchand, J., 1993. The influence of seasonal salinity and turbidity maximum variations on the nursery function of the Loire estuary (France). Neth. J. Aquat. Ecol. 27, 427-436. 
Norcross, B.L., Blanchard, A., Holladay, B.A., 1999. Comparaison of models for defining nearshore flatfish nursery areas in Alaskan waters. Fish Oceanogr. 9, 50-67.

Nottage, A.S., Perkins, E.J., 1983. The biology of solenette, Buglossidium luteum (Risso), in the Solway Firth. J. Fish Biol. 22, 21-27.

Riley, J.D., Symonds, D.J., Woolner, L., 1981. On the factors influencing the distribution of 0-group demersal fish in coastal waters. J. Cons. Int. Explor. Mer. 178, 223-228.

Rogers, S.I., 1992. Environmental factors affecting the distribution of Dover sole (Solea solea L.) within a nursery area. Neth. J. Sea Res. 29, 151-159.

Rogers, S.I., Rijnsdorp, A.D., Damm, U., Vanhee, W., 1998. Demersal fish populations in the coastal waters of the UK and continental NW Europe from beam trawl survey data collected from 1990 to 1995. J. Sea Res. 39, 79-102.

Stefanson, G., 1996. Analysis of groundfish survey abundance data: combining the GLM and delta approaches. ICES J. Mar. Sci. 53, 577-588.

Van der Veer, H.W., Phil, L., Bergman, M.J.N., 1990. Recruitment mechanisms in North Sea plaice Pleuronectes platessa. Mar. Ecol. Prog. Ser. 64, 1-12.

Wheeler, A., 1969. The fishes of the British Isles and north west Europe. Mac Millon, London, 1529.

Zijlstra, J.J., 1972. On the importance of the Wadden Sea as a nursery area in relation to the conservation of the southern North Sea fishery resources. Symp. Zool. Soc. Lond. 29, 233-258. 
Figure legends

Fig. 1. Map of the studied area showing the sampling stations and the location of the main rivers.

Fig. 2. Distribution of solenette during autumn 1999 (a) and 2000 (b) in the Eastern Channel and southern North Sea and during autumn 2000 (c) and 2001 (d) in the Bay of Biscay. Densities were log-transformed, $y=\log (x+1)$.

Fig. 3. Distribution (percentage of presence (black bar) and abundance (white bar) of solenette in the Eastern Channel and the Bay of Biscay according to salinity (a), sediment (b) and depth classes (c).

Fig. 4. Growth curve of female (a) and male (b) solenette in the Bay of Somme (•), Seine (घ) and Vilaine (o). 


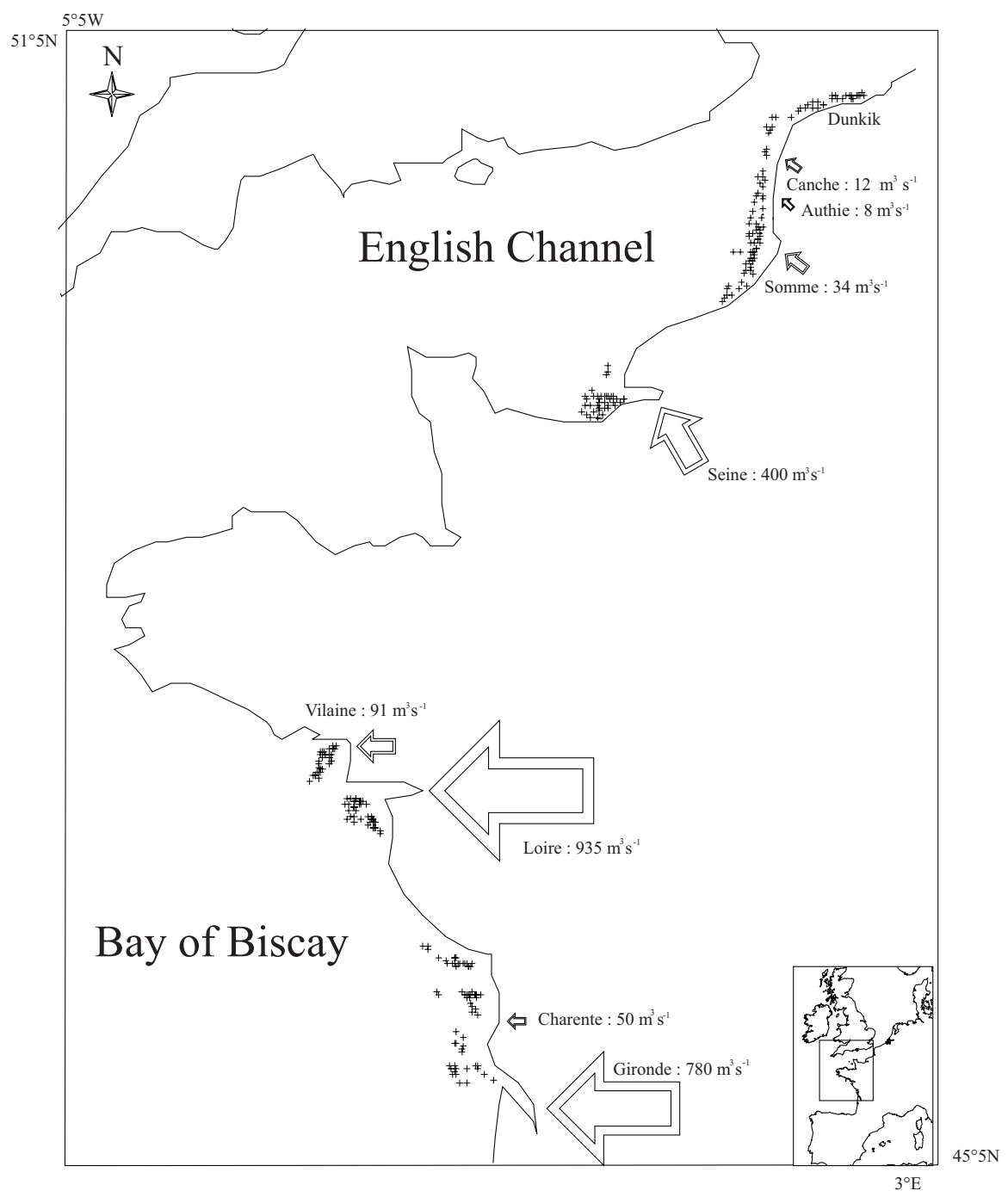

Figure 1. 

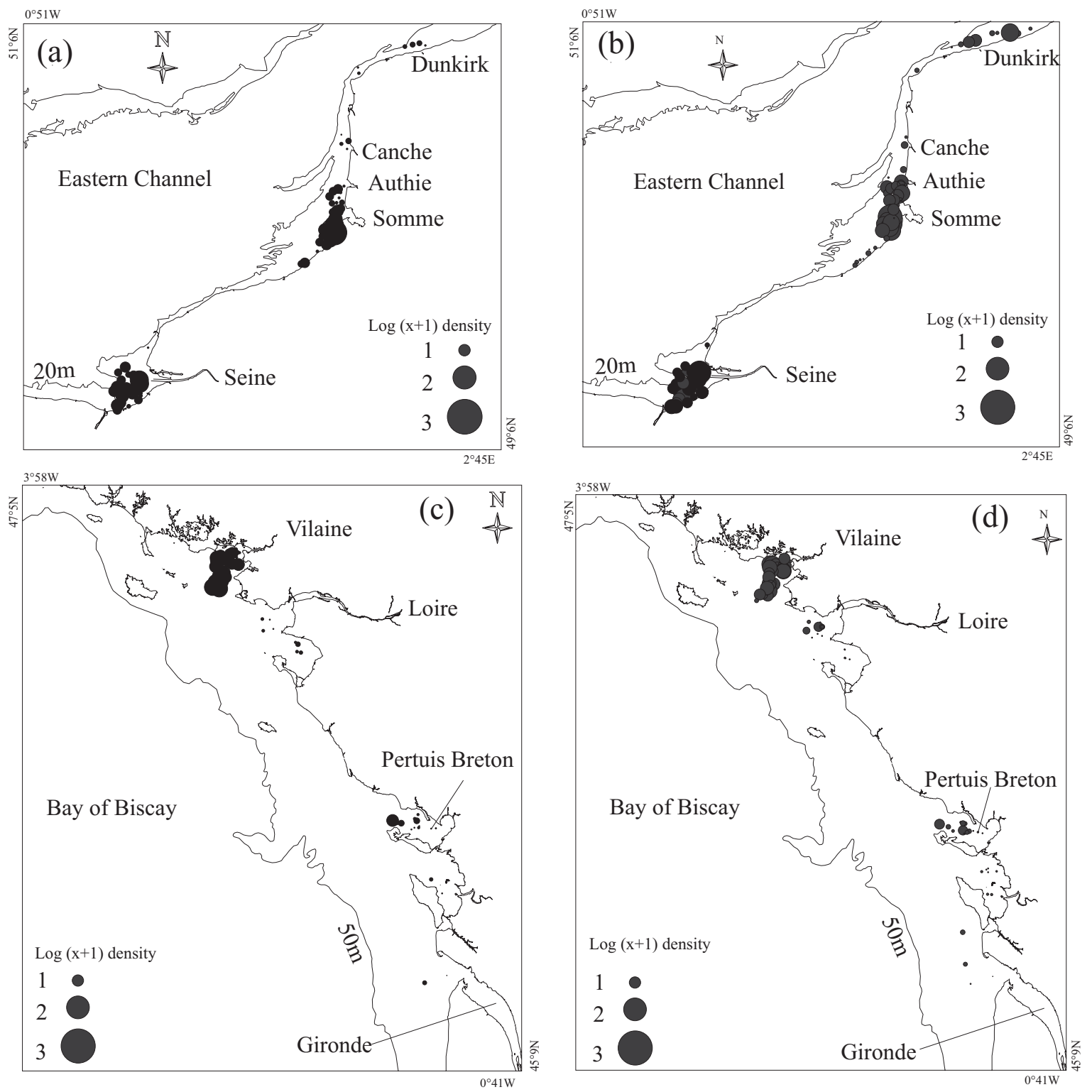

Figure 2. 
Eastern Channel
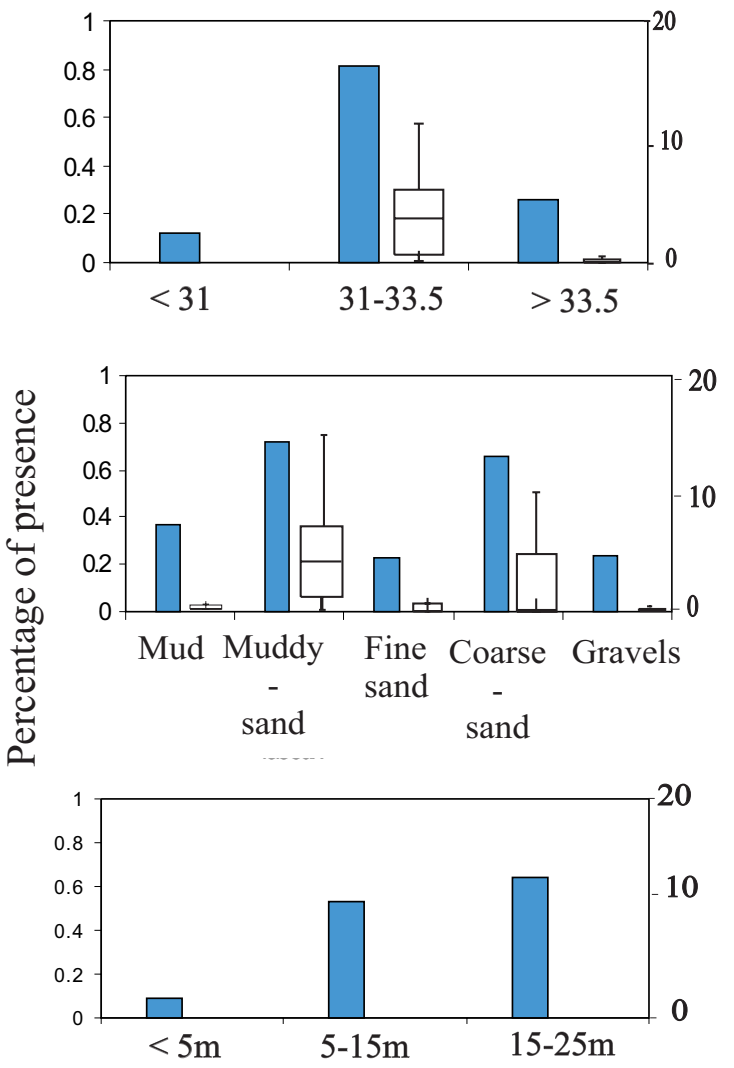

Bay of Biscay
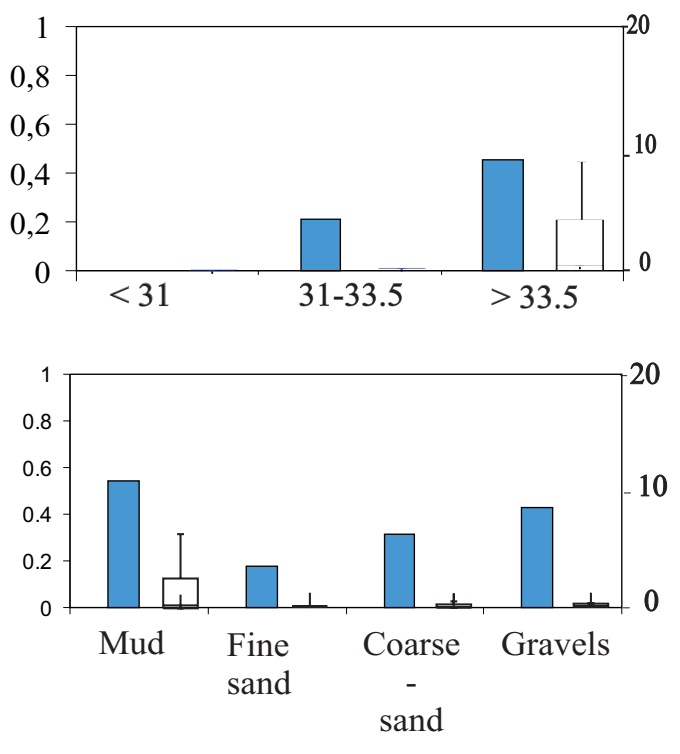

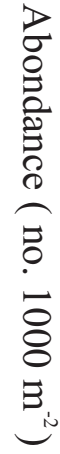

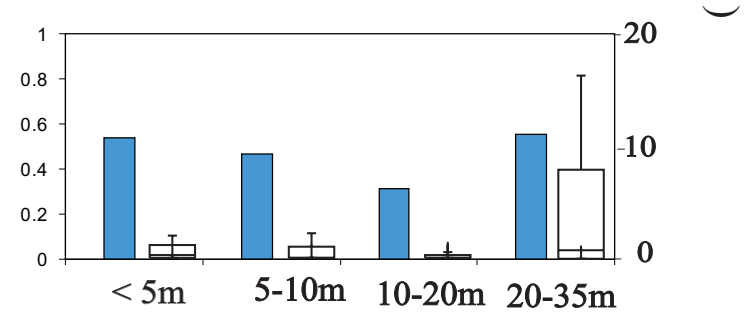

Figure 3. 


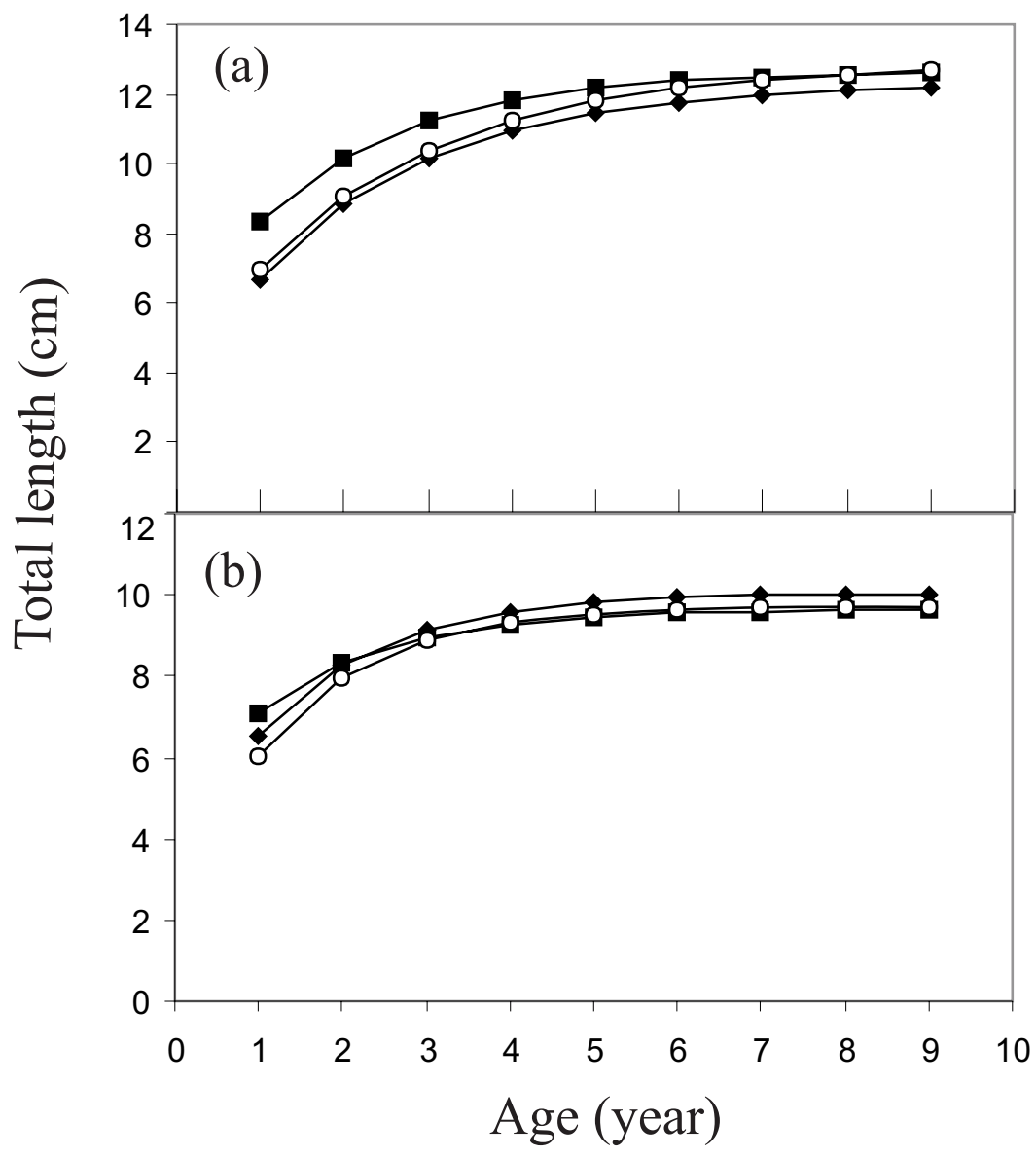

Figure 4. 